\title{
Genotoxicity of Some Essential Oils Frequently Used in Aromatherapy
}

\author{
Nadya Mezzoug1, Mohamed Idaomar1, Dominique Baudoux², Pascal Debauche², \\ Véronique Liemans ${ }^{2}$, Abdesselam Zhiri2* \\ ${ }^{1}$ Laboratory of Biology and Health, Faculté des Sciences, Université Abdelmalek Essaâdi, Tétouan, Morocco \\ ${ }^{2}$ S.A. PRANAROM International, Ghislenghien, Belgium

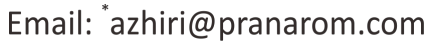

Received 22 October 2015; accepted 20 February 2016; published 23 February 2016

Copyright (C) 2016 by authors and Scientific Research Publishing Inc.

This work is licensed under the Creative Commons Attribution International License (CC BY). http://creativecommons.org/licenses/by/4.0/

(c) (i) Open Access

\begin{abstract}
Genotoxic properties of the essential oils extracted from Artemisia dracunculus (tarragon), Ocimum basilicum (basil), Cinnamomum loureirii (cinnamon), Laurus nobilis (laurel), Satureja montana (savory) and Rosmarinus officinallis (rosemary) are studied by Drosophila melanogaster Somatic Mutation and Recombination Test (SMART). The high bioactivation crossed with a high cytochrome P450-dependent bioactivation capacity is used. This assay is principally based on the loss of heterozygosity of the suitable recessive markers' multiple wing hairs ( $\mathrm{mwh}$ ) and flare-3 $\left(f l r^{3}\right)$ which can lead to the formation of mutant clones of larval cells, and which are then going to be expressed as spots on the wings of adult flies. Third-instar larvae are treated for $48 \mathrm{hr}$ with different concentrations of the essential oils dissolved in Tween-80 at $0.2 \%$ or $2 \%$. The wings of the emerging adults are analyzed for the occurrence of different types of mutant spots. No statistically significant differences in spot frequencies between negative controls and treated series are observed. These results suggest that the six essential oils at concentrations tested are not genotoxic towards somatic cells of $D$. melanogaster.
\end{abstract}

\section{Keywords}

Essential Oils, Genotoxicity, Somatic Mutation, Mitotic Recombination, Drosophila melanogaster

\section{Introduction}

Essential oils are natural volatile substances found in a variety of plants' particular fragrance. They are products of the secondary metabolism of plants, and generally are fragrant volatile materials consisting of a complex

"Corresponding author.

How to cite this paper: Mezzoug, N., Idaomar, M., Baudoux, D., Debauche, P., Liemans, V. and Zhiri, A. (2016) Genotoxicity of Some Essential Oils Frequently Used in Aromatherapy. Advances in Bioscience and Biotechnology, 7, 63-73. 
mixture of which the most common constituents are the monoterpene hydrocarbons, oxygenated monoterpenes, sesquiterpene hydrocarbons, oxygenated sesquiterpenes, benzene derivatives, and non-isoprenoid components including alcohols, aldehydes and ketones. The flavor-imparting essential oils' content of the spices, herbs and leafy vegetables is important and can represent more than $5 \%$ of their fresh mass [1]. The essential oils can be isolated from several parts of plant usually by using the distillation method.

Essential oils have been widely used in traditional medicine, as food additives or food preservatives as well as in aromatherapy and in the industries of perfumes and cosmetics. Over the last couple of years, there has been an increasing interest in the use of the essential oils as a large number of them have been investigated for their biological activities. Indeed, the antimicrobial properties of essential oils and their constituents against some bacteria and fungi are described in more than 500 reports [2]. Moreover, the antiphlogistic, cough-relieving and spasmolytic effects of essential oils have been observed in experimental animals [3]. Also the essential oils can play a significant role as antioxidant [4], insecticide [5] anti-inflammatory and antinociceptive [6]. Furthermore, the hepatoprotective [7] and anticarcinogenic activities of specific essential oils were revealed [8]. However, only few papers contain data on their toxicity, and less about their chronic toxicities such as teratogenesis, carcinogenesis and mutagenesis. Though, it must be noted that studies on genotoxicity of individual components of essential oils are much more abundant, about 30 constituents of essential oils, mainly monoterpenes and alkenylbenzenes, have been tested for their genotoxicity. About one-third of them have shown a genotoxic effect in one or several genotoxicity tests [9].

Based on this preliminary information, and led by our consistent interest to assess the genotoxic profile of our natural essences [10]-[12], the aim of the present study was to investigate the genotoxicity of six essential oils frequently used in aromatherapy by the Somatic Mutation and Recombination Test (SMART) in Drosophila melanogaster.

Genotoxicity tests were developed to detect genotoxic substances and to assess the genetic hazard of chemicals to humans. The tests in Drosophila melanogaster present undoubted advantages: they are an in vivo system that uses a eukaryotic organism with metabolic machinery similar to that found in mammalians cells [13] and which the genome sequencing has shown that half of the identified protein sequences are similar to the mammalian proteins [14]. On the other hand, those assays are also characterized by their rapidity as compared with that of prokaryotic or unicellular in vitro tests [15].

The SMART is a sensitive short-term assay for the detection of somatic mutation and mitotic recombination [13]. It has been widely used in both version based on eye or wing marker [16] [17]. In both cases loss of heterozygosity leads to uncovering and expression of the recessive marker gene(s) in the larval imaginal disc cells. The SMART assay has been extensively validated and a hundred of compounds and complex mixtures have been analysed since the assay was developed [18].

The SMART system using wing tissue is based on the markers $m w h$ (multiple wing hairs) and flr (flare) and takes advantage of the possibility to expose and analyze a large number of cells: approximately 25,000 cells in one wing [19]. If a genetic alteration occurs in larvae, this alteration will form a clone of mutant cells that can be detected as a spot of mutant cells on the body surface of the adult flies [19]. Single spots, either mwh or flr, can be produced by somatic point mutations or deletions and may also result from aneuploidy or chromosome loss [13] [20]. Single $m w h$ spots also arise from recombination between the $m w h$ and flr loci. Twin spots, consisting of both $m w h$ and flr subclones are originated exclusively from mitotic recombination [13] [20]. All of these mutational events detected by the wing SMART assay well permit to measure mutagenic damage that could be induced by the essential oils tested.

\section{Material and Methods}

\subsection{Essential Oils and Plant Material}

Oils of Cinnamomum loureirii (cinnamon), Artemisia dracunculus (tarragon), Laurus nobilis (laurel), Ocimum basilicum (basil), Rosmarinus officinallis (rosemary), and of Satureja montana (savory) are provided by PRANAROM International Company, Belgium. The plants were collected from different geographic areas in the world and are listed in Table 1 by plant species, common names as well as part used.

\subsection{Extraction and Identification of Essential Oils}

The essential oils were extracted by steam distillation. This was performed at a low pressure without chemical 
Table 1. Botanical names, location and part used of selected aromatic plant species.

\begin{tabular}{cccc}
\hline Botanical names & Common names & Location & Part used \\
\hline Cinnamomum loureirii & Cinnamon & Vietnam & Bark \\
Artemisia dracunculus & Tarragone & Iran & Flowering tops \\
Laurus nobilis & Laurel & Slovenia & Leaf \\
Ocimum basilicum & Basil & Madagascar & Flowering tops \\
Rosmarinus officinallis & Rosemary & France & Flowering tops \\
Satureja montana & Savory & France & Flowering tops \\
\hline
\end{tabular}

descalers. The essential oils analyses were carried out by GC/MS using a Hewlett-Packard GCD system. HPINNOWAX capillary column ( $60 \mathrm{~m} \times 0.25 \mathrm{~mm}, 0.5 \mu \mathrm{m}$ film thickness) was used with helium as carrier gas with flow 22 - 25 psi. GC oven temperature was held at $50^{\circ} \mathrm{C}$ for $6 \mathrm{~min}$, then programmed at $2^{\circ} \mathrm{C} / \mathrm{min}$ to $250^{\circ} \mathrm{C}$ and then held at this temperature for $20 \mathrm{~min}$. The injector and detector temperatures were $250^{\circ} \mathrm{C}$ and $280^{\circ} \mathrm{C}$, respectively, injection in split mode, volume injected $1 \mu \mathrm{l}$ of a solution 5/100 in hexane of the oil. Automatic calibration of the masses by autotuning was used in MS. Mass range was from $m / z 30$ to 350. Library search was carried out using the combination of NKS library with 75,000 spectra and a personnel aromatic library. Table 2 lists the oils major components obtained by gas chromatography analysis.

\subsection{Mutagenicity Assay}

For mutagenicity testings, the essentials oils were dissolved in the Tween- 80 at $0.2 \%$ or $2 \%$ depending on the solubility of the oils. The essential oils were administered to Drosophila larvae at different concentrations, ranging from $0.025 \%$ to $0.3 \%$. Solutions were always freshly prepared immediately before use. The solvents are also used as negative controls. Urethane (CAS registry number: 51-79-6) was used as positive control.

\subsubsection{Drosophila Stocks and Cross}

The high bioactivation cross was used when NORR/NORR; NORR/NORR; $f r^{3} / I n$ (3LR) TM3, ri p pep l(3)89Aa $b x^{34 e}$ e $B d^{s}\left(f l r^{3} / T M 3\right)$ females are crossed with NORR/NORR; NORR/NORR; $m w h / m w h$ males. NORR strains (New ORR) has chromosomes 1 and 2 from DDT-resistant which are responsible for a high constitutive level of cytochrome P450 [21]. The $m w h$ strain is homozygote for the wing cell marker multiple wing hairs ( $m w h, 3$ $0.3)$. The $f r^{3} / T M 3$ strain contains the wing cell marker allele flare3 $\left(f r^{3}, 3-38.8\right)$ and the balancer chromosomes TM. More detailed information on genetic markers and descriptions are given by Lindsley and Zimm [22].

\subsubsection{Experimental Procedures}

Eggs from the high bioactivation were collected for $8 \mathrm{~h}$ in culture bottles containing the live fermenting yeast. After $72 \pm 4 \mathrm{~h}$, the larvae were collected off the food with a $20 \% \mathrm{NaCl}$ solution. The larvae were transferred to individual vials containing $1.5 \mathrm{~g}$ of food prepared from Drosophila Instant Medium (Carolina Biological Supply) hydrated by $5 \mathrm{ml}$ of the essential oils dissolved in Tween-80 at different concentrations. The larvae were fed on this medium for the rest of their development which corresponds to a chronic treatment of approximately 48h until pupation. Negative solvent controls were included in all treatments. All experiments were conducted at $25^{\circ} \mathrm{C}$ and $65 \%$ relative humidity.

The hatched flies were collected from the treatment vials and flies of the trans-heterozygous ( $m w h$ flr $+/ m w h$ $+f l r)$ genotype were stored in $70 \%$ ethanol. The wings of adult flies were mounted on slides and scored under $400 \times$ magnification for the presence of cell clones showing malformed wing hairs. Such spots appeared as single spots expressing either the multiple wing hair $(m w h)$ or flare (flr) phenotype or as twin spots with adjacent $m w h$ and $f l r$ areas.

\subsection{Data Evaluation and Statistical Analysis}

For the evaluation of the recorded genotoxic effects, the frequencies of spots per fly of a treated series were compared to its concurrent negative control. Statistical analyses have been conducted using a Chi-square test. 
Table 2. Major chemical components of Cinnamomum loureirii, Artemisia dracunculus, Laurus nobilis, Ocimum basilicum, Rosmarinus officinallis and Satureja montana essential oils.

\begin{tabular}{|c|c|c|c|c|c|c|}
\hline & C. loureirii & A. dracunculus & L. nobilis & O. basilicum & R. officinallis & S. montana \\
\hline$\alpha$-Pinene & - & 1.19 & 4.13 & 0.24 & 26.48 & 1.10 \\
\hline Camphene & - & - & 0.41 & - & 6.21 & 0.69 \\
\hline$\beta$-Pinene & - & - & 3.48 & 0.41 & 2.66 & 0.42 \\
\hline P-Menthatriene & - & - & - & - & 1.48 & - \\
\hline Sabinene & - & - & 6.53 & 0.15 & - & - \\
\hline Benzene propanal & 1.32 & - & - & - & - & - \\
\hline$\beta$-Myrcene & - & 0.10 & 0.94 & 0.20 & 1.50 & 0.89 \\
\hline 1,8-Cineole & - & - & 38.73 & 4.02 & 10.71 & 1.32 \\
\hline Limonene & - & 3.04 & 1.47 & 0.32 & 3.61 & 0.95 \\
\hline Cis- $\beta$-ocimene & - & 8.49 & - & 0.13 & 0.16 & 0.35 \\
\hline Cinnamaldehyde & 81.66 & - & - & - & - & - \\
\hline Trans- $\beta$-ocimene & - & 10.05 & - & 1.47 & - & 0.10 \\
\hline$\gamma$-Terpinene & - & - & 0.88 & 0.13 & 1.35 & 7.01 \\
\hline P-Cymene & - & - & 0.53 & 0.09 & 1.98 & 9.85 \\
\hline Terpinolene & - & - & 0.40 & - & 0.73 & 0.16 \\
\hline$\alpha$-Copaene & 1.55 & - & - & - & - & - \\
\hline$\beta$-Caryophyllene & 0.66 & - & 0.50 & 0.56 & 0.32 & 1.20 \\
\hline Coumarine $\mathrm{mw}=146$ & 2.63 & - & - & - & - & - \\
\hline Cinnamyle acetate & 3.66 & - & - & - & - & - \\
\hline Camphre & - & - & - & 0.24 & 2.82 & 1.28 \\
\hline Linalol & - & - & 7.77 & 1.89 & 2.84 & 2.42 \\
\hline Bornyle acetate & - & - & 0.53 & 0.45 & 13.19 & 0.49 \\
\hline Carvacrol methyl ether & - & - & - & - & - & 4.88 \\
\hline Terpinene-4-ol & - & - & 3.49 & 0.60 & 1.18 & 0.91 \\
\hline Methyl chavicol & - & 75.23 & 0.08 & 77.41 & 0.13 & - \\
\hline$\alpha$-Terpineol & - & - & 3.21 & 0.20 & 1.32 & 1.88 \\
\hline Terpenyle acetate & - & - & 12.34 & - & - & - \\
\hline Borneol & - & - & 0.12 & 0.10 & 4.45 & 3.41 \\
\hline Verbenone & - & - & - & - & 7.27 & - \\
\hline Carvone & - & - & - & - & 0.11 & 0.83 \\
\hline$\delta$-Cadinene & 0.89 & - & 0.13 & - & - & 0.50 \\
\hline Geraniol & - & - & - & - & 1.33 & - \\
\hline Methyleugenol & - & 0.71 & 6.79 & 3.75 & 0.11 & 0.54 \\
\hline Eugenol & - & 0.31 & 1.97 & 0.14 & - & 0.19 \\
\hline T-Cadinol & - & - & - & 1.66 & - & - \\
\hline Thymol & - & - & - & - & - & 10.59 \\
\hline Carvacrol & - & - & - & - & - & 36.67 \\
\hline
\end{tabular}


Accordingly we distinguished small single spots (one or two cells affected), large single spots (more than two cells affected) and twin spots.

\section{Results}

Before starting the genotoxicity experiments, toxicity is evaluated in the first instance in order to determine the concentrations that are going to be tested in the wing spot test. The toxicity shown in Table 3 was measured by determining the fraction of the larvae developing to adulthood in comparison with negative controls. All six essential oils tested present toxicity in $48 \mathrm{~h}$ larval feeding experiments at different degrees. At a concentration of $0.3 \%$, the essential oils of Artemisia dracunculus, Ocimum basilicum and Cinnamomum loureirii were shown to be very toxic for larvae and no adult flies survived. The essential oil from Satureja montana was less toxic at this concentration. For their part, Laurus nobilis and Rosmarinus officinalis presented weak toxicity at $0.3 \%$.

The results of the genotoxicity study obtained with the six essential oils in the Drosophila wing spots test after chronic exposure are shown in Table 4. The spot data for small single spots, large single spots and twin spots

Table 3. Toxicity of the essentials oils tested expressed in \% of lethality of the treated larvae.

\begin{tabular}{|c|c|c|}
\hline Oil & Dose (\%) & Toxicity (\%) \\
\hline \multicolumn{3}{|c|}{ Artemisia dracunculus } \\
\hline & 0.3 & 100 \\
\hline & 0.2 & $90-100$ \\
\hline & 0.1 & $25-50$ \\
\hline & 0.05 & $5-10$ \\
\hline \multicolumn{3}{|c|}{ Ocimum basilicum } \\
\hline & 0.3 & 100 \\
\hline & 0.2 & $90-100$ \\
\hline & 0.1 & 50 \\
\hline & 0.05 & $5-10$ \\
\hline \multicolumn{3}{|c|}{ Cinnamomum loureirii } \\
\hline & 0.3 & 100 \\
\hline & 0.2 & $80-100$ \\
\hline & 0.1 & $50-75$ \\
\hline & 0.05 & $25-50$ \\
\hline \multicolumn{3}{|c|}{ Satureja montana } \\
\hline & 0.3 & $80-100$ \\
\hline & 0.2 & 50 \\
\hline & 0.1 & $10-25$ \\
\hline & 0.05 & $5-10$ \\
\hline \multicolumn{3}{|c|}{ Laurus nobilis } \\
\hline & 0.3 & 25 \\
\hline & 0.2 & $10-20$ \\
\hline & 0.1 & $5-10$ \\
\hline \multicolumn{3}{|c|}{ Rosmarinus officinallis } \\
\hline & 0.3 & 25 \\
\hline & 0.2 & $10-20$ \\
\hline & 0.1 & $5-10$ \\
\hline
\end{tabular}


Table 4. Wing spots data obtained after chronic exposure with the essential oils.

\begin{tabular}{|c|c|c|c|c|c|}
\hline \multirow{2}{*}{$\begin{array}{c}\text { Compounds } \\
\text { concentration (\%) }\end{array}$} & \multirow{2}{*}{$\begin{array}{l}\text { Number of } \\
\text { wings }\end{array}$} & \multicolumn{4}{|c|}{ Spots per wing (number of spots) } \\
\hline & & Small single spots & Large single spots & Twin spots & Total spots \\
\hline \multicolumn{6}{|c|}{ Cinnamomum loureirii } \\
\hline Tween-80 0.2\% & 71 & $0.28(20)$ & $0.06(04)$ & $0.00(00)$ & $0.34(24)$ \\
\hline 0.025 & 40 & $0.27^{\mathrm{a}}(11)$ & $0.00^{\mathrm{a}}(00)$ & $0.00^{\mathrm{a}}(00)$ & $0.27^{\mathrm{a}}(11)$ \\
\hline 0.05 & 40 & $0.40^{\mathrm{a}}(16)$ & $0.02^{\mathrm{a}}(01)$ & $0.00^{\mathrm{a}}(00)$ & $0.42^{\mathrm{a}}(17)$ \\
\hline 0.1 & 40 & $0.35^{\mathrm{a}}(14)$ & $0.00^{\mathrm{a}}(00)$ & $0.00^{\mathrm{a}}(00)$ & $0.35^{\mathrm{a}}(14)$ \\
\hline \multicolumn{6}{|c|}{ Artemisia dracunculus } \\
\hline Tween-80 0.2\% & 71 & $0.28(20)$ & $0.06(04)$ & $0.00(00)$ & $0.34(24)$ \\
\hline 0.025 & 40 & $0.35^{\mathrm{a}}(14)$ & $0.00^{\mathrm{a}}(00)$ & $0.00^{\mathrm{a}}(00)$ & $0.35^{\mathrm{a}}(14)$ \\
\hline 0.05 & 42 & $0.45^{\mathrm{a}}(19)$ & $0.10^{\mathrm{a}}(04)$ & $0.00^{\mathrm{a}}(00)$ & $0.55^{\mathrm{a}}(23)$ \\
\hline 0.1 & 25 & $0.32^{\mathrm{a}}(08)$ & $0.20^{\mathrm{a}}(05)$ & $0.00^{\mathrm{a}}(00)$ & $0.52^{\mathrm{a}}(13)$ \\
\hline \multicolumn{6}{|l|}{ Laurus nobilis } \\
\hline Tween-80 2\% & 158 & $0.52(82)$ & $0.04(06)$ & $0.00(00)$ & $0.56(88)$ \\
\hline 0.1 & 40 & $0.43^{\mathrm{a}}(17)$ & $0.02^{\mathrm{a}}(01)$ & $0.00^{\mathrm{a}}(00)$ & $0.45^{\mathrm{a}}(18)$ \\
\hline 0.2 & 32 & $0.34^{\mathrm{a}}(11)$ & $0.09^{\mathrm{a}}(03)$ & $0.00^{\mathrm{a}}(00)$ & $0.43^{\mathrm{a}}(14)$ \\
\hline 0.3 & 39 & $0.41^{\mathrm{a}}(16)$ & $0.03^{\mathrm{a}}(01)$ & $0.00^{\mathrm{a}}(00)$ & $0.44^{\mathrm{a}}(17)$ \\
\hline \multicolumn{6}{|l|}{ Ocimum basilicum } \\
\hline Tween-80 2\% & 158 & $0.52(82)$ & $0.04(06)$ & $0.00(00)$ & $0.56(88)$ \\
\hline 0.025 & 40 & $0.32^{\mathrm{a}}(13)$ & $0.00^{\mathrm{a}}(00)$ & $0.00^{\mathrm{a}}(00)$ & $0.32^{\mathrm{a}}(13)$ \\
\hline 0.05 & 40 & $0.50^{\mathrm{a}}(20)$ & $0.05^{\mathrm{a}}(02)$ & $0.00^{\mathrm{a}}(00)$ & $0.55^{\mathrm{a}}(22)$ \\
\hline 0.1 & 40 & $0.30^{\mathrm{a}}(12)$ & $0.02^{\mathrm{a}}(01)$ & $0.00^{\mathrm{a}}(00)$ & $0.32^{\mathrm{a}}(13)$ \\
\hline \multicolumn{6}{|l|}{ Rosmarinus officinallis } \\
\hline Tween-80 2\% & 158 & $0.52(82)$ & $0.04(06)$ & $0.00(00)$ & $0.56(88)$ \\
\hline 0.1 & 40 & $0.45^{\mathrm{a}}(18)$ & $0.10^{\mathrm{a}}(04)$ & $0.00^{\mathrm{a}}(00)$ & $0.55^{\mathrm{a}}(22)$ \\
\hline 0.2 & 40 & $0.35^{\mathrm{a}}(14)$ & $0.02^{\mathrm{a}}(01)$ & $0.00^{\mathrm{a}}(00)$ & $0.37^{\mathrm{a}}(15)$ \\
\hline \multicolumn{6}{|l|}{ Satureja montana } \\
\hline Tween-80 2\% & 158 & $0.52(82)$ & $0.04(06)$ & $0.00(00)$ & $0.56(88)$ \\
\hline 0.05 & 37 & $0.68^{\mathrm{a}}(25)$ & $0.08^{\mathrm{a}}(03)$ & $0.00^{\mathrm{a}}(00)$ & $0.76^{\mathrm{a}}(28)$ \\
\hline 0.1 & 33 & $0.45^{\mathrm{a}}(15)$ & $0.06^{\mathrm{a}}(02)$ & $0.00^{\mathrm{a}}(00)$ & $0.51^{\mathrm{a}}(17)$ \\
\hline \multicolumn{6}{|l|}{ Urethane } \\
\hline Distilled water & 40 & $0.30(12)$ & $0.03(01)$ & $0.00(00)$ & $0.33(13)$ \\
\hline $5 \mathrm{mM}$ & 40 & $2.53^{\mathrm{d}}(101)$ & $0.65^{\mathrm{d}}(26)$ & $0.27^{\mathrm{C}}(11)$ & $3.45^{\mathrm{d}}(138)$ \\
\hline
\end{tabular}

${ }^{\mathrm{a}} p>0.05 ;{ }^{\mathrm{c}} p<0.01 ;{ }^{\mathrm{d}} p<0.001$.

together with the total number of spots are presented. Different concentrations of each compound were assessed using larvae of the high bioactivation cross. The compounds were dissolved in Tween-80 $0.2 \%$ or Tween-80 $2 \%$. Urethane was dissolved in distilled water. For each essential oil, the treated series were compared with the nega- 
tive control corresponding to the pooled results of the spontaneous mutations detected for the corresponding solvent used. The spontaneous frequency of total Spots obtained in Tween-80 2\% (0.56) was higher than the value in the Tween-80 0.2\% (0.34) and statistically different. Moreover, there was no significant difference between mutations detected with the Tween- $800.2 \%$ and water (0.33). Urethane at $5 \mathrm{mM}$ increased significantly $(p<0.001)$ the small single spots, large simple spots, and the total of spots. The induction of the small size clone was more important than that of the large clones. Also the frequency of twin spots was increased $(p<0.01)$ in the presence of this promutagen.

Around and/or low concentrations than LC50 were chosen for all the six essential oils to conduct the genotoxicity experiments. The number of spots as well as their type and size were recorded. Two basic types of spots, single and twin, could be observed in the SMART assay. In our treatments, small single spots predominated; large single spots were rare whereas twin spots were absent. Most $m w h$ clones were small sizes; however, clones that are larger than 32 cells were absent. Among single spots in six different series, only few flr spots were observed; all other single spots showed the $m w h$ phenotype partly because the majority of the clones detected are small sizes and a mutational event at the flr+ does not express itself in clone smaller than a certain size [23]. Moreover, $\mathrm{flr}^{3}$ probably arises from relatively rare events like point mutations at the locus, interstitial deletions and perhaps double crossing-over [24]. Twin spots are absent, partly because only rare mitotic recombination events which take place between the flr locus and the centromere produce this type of spot [13].

From the statistically treated data summarized on Table 4 it can be pointed out that, the essential oils tested do not induce a significant increase in the frequency on any of the three categories of spots. Although an increase of the frequencies of mutations was observed with Satureja montana and Artemisia dracunculus essential oils in comparison with the negative solvent control; but this increase in mutant frequency was not considered biologically significant as there was no evidence of a dose-response effect. Also a weak increase was detected with the essential oil from Cinnamomum loureirii at $0.05 \%$ that remains not statistically or biologically significant. However, there was no increase of frequencies for other essential oils tested. In addition, a reduction in the rate of spontaneous mutations was observed for these oils, this effect being dose dependant for Rosmarinus officinallis contrarily to Laurus nobilis and Ocimum basilicum oils.

\section{Discussion}

After the exposition of the larvae of Drosophila melanogaster to the studied essential oils, a significant toxicity effect was observed. Many of plant secondary products are known for their high toxicity, and they are involved in plant defence mechanisms against herbivores as well as insects. This is the case of essential oils of which the insecticidal action was already demonstrated [5] [25]. In addition, the strains used in SMART assays are characterized by a high level of P450 [21], which is known for its role in the metabolism of several insecticides and plant toxins [26].

All the six essential oils tested are not genotoxic. These results are in agreement with the results previously shown by other authors using different assays, which demonstrated the absence of the genotoxicity of a great number of essential oils and stated out that only few essential oils are genotoxic [10] [12] [27]-[32]. But it must be noted that the positive results demonstrating the genotoxic effect of many essential oils were also found [9]. Positive and negative results about some of the oils tested in our study were reported; the genotoxic properties of Artemisia dracunculus and Satureja montana essential oils were studied with Bacillus subtilis Rec-assay and Salmonella/microsome reversion assay; only the oil of Artemisia dracunculus can be active in the Rec-assay but not in the Salmonella test [29]. With respect to our results, the Tarragon essential oil did not confirm its genotoxic potential in the Drosophila wing spot test even if the frequencies of spots detected in the treatments with this essential oil were weakly enhanced, but without statistical significance. Cinnamon bark oil was studied in the Ames Salmonella reversion assay, in the Bacillus subtilis DNA-repair test (Rec-assay) without S9 and in the Escherichia coli WP2 uvrA reversion test, and showed negative results in the 3 microbial test systems [27]. This negative effect of Cinnamon essential oil was confirmed by SMART assay in our study. However, a genotoxic potential of the Basil essential oil in rat hepatocytes in vitro and in rat liver in an in vivo test was demonstrated [33] but not with SMART assay according to our results.

On the other hand, the main components of essential oils have been tested for their mutagenicity by a range of genotoxicity tests, and produced contradictory results. The negative mutagenic effect, which can confirm our results, was found in the Ames Salmonella reversion assay and in the Escherichia coli WP2 uvrA reversion test 
with methyl chavicol, which is present in both Artimisia dracunculus essential oil at $75.23 \%$ and Ocimum basilicum oil at 77.41\%, and with cinnamaldehyde, the main compound of Cinnamomum loureirii essential oil (81.66\%) [27] [34]. Cinnamaldehyde did not cause any DNA damage in the SOS-chromotest [35]. However, this compound exhibited a weak mutagenic response in TA100 Salmonella strain with mouse liver S9 [36] and gave a positive response in the E. coli DNA repair test [35]. It has been reported that cinnamaldehyde was positive in a Drosophila sex-linked recessive lethal mutation test and in a chromosomal aberration test with Chinese hamster fibroblasts [37]. A positive effect was also detected in the Bacillus subtilis DNA-repair test (Rec-assay) with cinnamaldehyde and with methyl chavicol [27]. 1,8-Cineole, an important molecule found in Laurel oil and even more present in Rosemary essential oil, did not show any mutagenic effect by the Salmonella assay [32]. Thymol was screened for mutagenic activity using the same test; no effect was detected with this important savory oil compound [34]. Thymol was also tested in vitro on human pulp fibroblasts without any genotoxic effect [38]. However, weak significant genotoxic effect was observed in the DNA repair test with thymol and also with carvacrol which is the major constituent of the savory essential oil [35]. In the SOS-chromotest, none of the carvacrol and thymol was positive [35].

The genotoxicity tests were negative for d-limonene which is present in all essential oils at different proportions [39]. Also, no evidence of myrcene-induced clastogenicity was observed using the rat bone marrow cytogenetic in vivo assay [40] and no mutagenic effect in Salmonella typhimurium with borneol was detected [34]. However, the Terpineol present in many essential oils tested caused a slight but dose-related increase in the number of his + revertants with TA102 Salmonella tester strain both without and with addition of S9 mixture [32]. For their part, methyl eugenol and eugenol did not show mutagenicity in the Ames assay and in the Escherichia coli WP2 uvrA reversion test [27] [34]. In the human pulp fibroblasts in vitro, eugenol did not show any genotoxic effect [38]. But using the bone marrow micronucleus assay in mice, eugenol showed a significant induction of micronucleus in 400 and $600 \mathrm{mg} / \mathrm{kg}$ doses [41]. Mutagenic capacity of eugenol was also demonstrated by in vivo eukaryotic assays on mice [42].

Thus, the evaluation of the genotoxicity of the components of essential oils showed data that can vary according to the organism and the genotoxic assay used. Moreover, the negative results obtained in the present study suggest that the studied essential oils for the tested concentrations are not genotoxic in D. melanogaster. This is not always in accordance with the data of some of their constituents. This can be explained by the antagonistic phenomena when some antimutagenic compounds can be present in the oils tested and oppose the mutagenic effect of other components of the mixture of essential oil. Further experiments are suggested to evaluate possible antigenotoxic properties of these oils or some of their constituents.

\section{Acknowledgements}

This work was supported by PRANAROM International Company and the Ministry of Walloon Region, Belgium (Direction générale des technologies, de la recherche et de l'énergie, Promotion de l'innovation technique, Jambe-Namur).

\section{References}

[1] Achinewhu, S.C., Ogbonna, C.C. and Hart, A.D. (1995) Chemical Composition of Indigenous Wild Herbs, Spices, Nuts and Leafy Vegetables Used as Food. Plant Foods for Human Nutrition, 48, 341-348. http://dx.doi.org/10.1007/BF01088493

[2] Kalemba, D. and Kunicka, A. (2003) Antibacterial and Antifungal Properties of Essential Oils. Current Medicinal Chemistry, 10, 813-829. http://dx.doi.org/10.2174/0929867033457719

[3] Inouye, S., Yamaguchi, H. and Takizawa, T. (2001) Screening of the Antibacterial Effects of a Variety of Essential Oils on Respiratory Tract Pathogens, Using a Modified Dilution Assay Method. Journal of Infection and Chemotherapy, 7, 251-254. http://dx.doi.org/10.1007/s101560170022

[4] Miguel, M.G. (2010) Antioxidant and Anti-Inflammatory Activities of Essential Oils: A Short Review. Molecules, 15, 9252-9287. http://dx.doi.org/10.3390/molecules15129252

[5] Liu, Z.L., Chu, S.S. and Liu, Q.R. (2010) Chemical Composition and Insecticidal Activity against Sitophilus zeamais of the Essential Oils of Artemisia capillaris and Artemisia mongolica. Molecules, 15, 2600-2608. http://dx.doi.org/10.3390/molecules15042600

[6] Leite, B.L., Bonfim, R.R., Antoniolli, A.R., Thomazzi, S.M., Araújo, A.A., Blank, A.F., Estevam, C.S., Cambui, E.V., 
Bonjardim, L.R., Albuquerque Júnior, R.L. and Quintans-Júnior, L.J. (2010) Assessment of Antinociceptive, Anti-Inflammatory and Antioxidant Properties of Cymbopogon winterianus Leaf Essential Oil. Pharmaceutical Biology, 10, 1164-1169. http://dx.doi.org/10.3109/13880200903280000

[7] Samojlik, I., Lakić, N., Mimica-Dukić, N., Daković-Svajcer, K. and Bozin, B. (2010) Antioxidant and Hepatoprotective Potential of Essential Oils of Coriander (Coriandrum sativum L.) and Caraway (Carum carvi L.) (Apiaceae). Journal of Agricultural and Food Chemistry, 58, 8848-8853. http://dx.doi.org/10.1021/jf101645n

[8] Edris, A.E. (2009) Anti-Cancer Properties of Nigella spp. Essential Oils and Their Major Constituents, Thymoquinone and Beta-Elemene. Current Clinical Pharmacology, 4, 43-46. http://dx.doi.org/10.2174/157488409787236137

[9] Lazutka, J.R., Mierauskiene, J., Slapsyte, G. and Dedonyte, V. (2001) Genotoxicity of Dill (Anethum graveolens L.), Peppermint (Menthaxpiperita L.) and Pine (Pinus sylvestris L.) Essential Oils in Human Lymphocytes and Drosophila melanogaster. Food and Chemical Toxicology, 39, 485-492. http://dx.doi.org/10.1016/S0278-6915(00)00157-5

[10] Idaomar, M., El Hamss, R., Bakkali, F., Mezzoug, N., Zhiri, A., Baudoux, D., Munoz-Serrano, A., Liemans, V. and Alonso-Moraga, A. (2002) Genotoxicity and Antigenotoxicity of Some Essential Oils Evaluated by Wing Spot Test of Drosophila melanogaster. Mutation Research, 513, 61-68. http://dx.doi.org/10.1016/S1383-5718(01)00287-X

[11] El Hamss, R., Idaomar, M., Alonso-Moraga, A. and Munoz Serrano, A. (2003) Antimutagenic Properties of Bell and Black Peppers. Food and Chemical Toxicology, 41, 41-47. http://dx.doi.org/10.1016/S0278-6915(02)00216-8

[12] Mezzoug, N., Elhadri, A., Dallouh, A., Amkiss, S., Skali, N.S., Abrini, J., Zhiri, A., Baudoux, D., Diallo, B., El Jaziri, M. and Idaomar, M. (2007) Investigation of the Mutagenic and Antimutagenic Effects of Origanum compactum Essential Oil and Some of Its Constituents. Mutation Research, 629, 100-110. http://dx.doi.org/10.1016/j.mrgentox.2007.01.011

[13] Graf, U., Würgler, F.E., Katz, A.J., Frei, H., Juon, H., Hall, C.B. and Kale, P.G. (1984) Somatic Mutation and Recombination Test in Drosophila melanogaster. Environmental Mutagenesis, 6, 153-188. http://dx.doi.org/10.1002/em.2860060206

[14] Rubin, G.M., Yandell, M.D., Wortman, J.R., Gabor Miklos, G.L., Nelson, C.R., Hariharan, I.K., et al. (2000) Comparative Genomics of the Eukaryotes. Science, 287, 2204-2215. http://dx.doi.org/10.1126/science.287.5461.2204

[15] Vogel, E.W. (1992) Tests for Recombinagens in Somatic Cells of Drosophila. Mutation Research, 284, $159-175$. http://dx.doi.org/10.1016/0027-5107(92)90030-6

[16] Vogel, E.W. and Zijlstra, J.A. (1987) Mechanistic and Methodological Aspects of Chemically-Induced Somatic Mutation and Recombination in Drosophila melanogaster. Mutation Research, 182, 243-264. http://dx.doi.org/10.1016/0165-1161(87)90010-0

[17] Vogel, E.W. and Nivard, M.J. (1993) Performance of 181 Chemicals in a Drosophila Assay Predominantly Monitoring Interchromosomal Mitotic Recombination. Mutagenesis, 8, 57-81. http://dx.doi.org/10.1093/mutage/8.1.57

[18] Delgado-Rodriguez, A., Ortiz-Marttelo, R., Villalobos-Pietrini, R., Gomez-Arroyo, S. and Graf, U. (1999) Genotoxicity of Organic Extracts of Airborne Particles in Somatic Cells of Drosophila melanogaster. Chemosphere, 39, 33-43. http://dx.doi.org/10.1016/S0045-6535(98)00586-4

[19] Guzmán-Rincón, J. and Graf, U. (1995) Drosophila melanogaster Somatic Mutation and Recombination Test as a Biomonitor. In: Butterworth, F.M., Corkun, L.D. and Guzmán-Rincón, J., Eds., Biomonitors and Biomarkers of Environment Change, Plenum Press, New York, 169-181.

[20] Graf, U., Juon, H., Katz, A.J., Frei, H.J. and Wurgler, F.E. (1983) A Pilot Study on a New Drosophila Spot Test. Mutation Research, 120, 233-239. http://dx.doi.org/10.1016/0165-7992(83)90095-7

[21] Frölich, A. and Würgler, F.E. (1989) New Tester Strains with Improved Bioactivation Capacity for the Drosophila Wing-Spot Test. Mutation Research, 216, 179-187. http://dx.doi.org/10.1016/0165-1161(89)90003-4

[22] Lindsley, D.L. and Zimm, G.G. (1992) The Genome of Drosophila melanogaster. Academic Press, San Diego, 1133.

[23] Szabad, J., Soos, I., Polgar, G. and Hejja, G. (1983) Testing the Mutagenicity of Malondialdehyde and Formaldehyde by the Drosophila Mosaic and the Sex-Linked Recessive Lethal Tests. Mutation Research, 113, 117-133. http://dx.doi.org/10.1016/0165-1161(83)90224-8

[24] Spano, M.A., Frei, H., Würgler, F.E. and Graf, U. (2001) Recombinagenic Activity of Four Compounds in the Standard and High Bioactivation Crosses of Drosophila melanogaster in the Wing Spot Test. Mutagenesis, 16, 385-394. http://dx.doi.org/10.1093/mutage/16.5.385

[25] Isman, B.M. (2000) Plant Essential Oils for Pest and Disease Management. Crop Protection, 19, 603-608. http://dx.doi.org/10.1016/S0261-2194(00)00079-X

[26] Scott, J.G., Liu, N. and Wen, Z. (1998) Insect Cytochromes P450: Diversity, Insecticide Resistance and Tolerance to Plant Toxins. Comparative Biochemistry and Physiology, Part C, Pharmacology, Toxicology and Endocrinology, 121, 147-155. http://dx.doi.org/10.1016/S0742-8413(98)10035-X 
[27] Sekizawa, J. and Shibamoto, T. (1982) Genotoxicity of Safrole-Related Chemicals in Microbial Test Systems. Mutation Research, 101, 127-140. http://dx.doi.org/10.1016/0165-1218(82)90003-9

[28] Andersen, P.H. and Jensen, N.J. (1984) Mutagenic Investigation of Flavourings: Dimethyl Succinate, Ethyl Pyruvate and Aconitic Acid Are Negative in the Salmonella/Mammalian-Microsome Test. Food Additives and Contaminants, 1, 283-288. http://dx.doi.org/10.1080/02652038409385855

[29] Zani, F., Massimo, G., Benvenuti, S., Bianchi, A., Albasini, A., Melegari, M., Vampa, G., Bellotti, A. and Mazza, P. (1991) Studies on the Genotoxic Properties of Essential Oils with Bacillus subtilis Recassay and Salmonella/Microsome Reversion Assay. Planta Medica, 57, 237-241. http://dx.doi.org/10.1055/s-2006-960081

[30] Franzios, G., Mirotsou, M., Hatziapostolou, E., Kral, J., Scouras, Z.G. and Mavragrani-Tsipidou, P. (1997) Insecticidal and Genotoxic Activities of Mint Essential Oils. Journal of Agricultural and Food Chemistry, 45, 2690-2694. http://dx.doi.org/10.1021/jf960685f

[31] Karpouhtsis, I., Pardali, E., Feggou, E., Kokkini, S., Scouras, Z.G. and Mavragani-Tsipidou, P. (1998) Insecticidal and Genotoxic Activities of Oregano Essential Oils. Journal of Agricultural and Food Chemistry, 46, 1111-1115. http://dx.doi.org/10.1021/jf9708220

[32] Padilha de Paula, J., Gomes-Carneiro, M.R. and Paumgartten, F.J. (2003) Chemical Composition, Toxicity and Mosquito Repellency of Ocimum selloi Oil. Journal of Agricultural and Food Chemistry, 88, 253-260. http://dx.doi.org/10.1016/S0378-8741(03)00233-2

[33] Muller, L., Kasper, P., Muller-Tegethoff, K. and Petr, T. (1994) The Genotoxic Potential in Vitro and in Vivo of the Allyl Benzene Etheric Oils Estragole, Basil Oil and Transanethole. Mutation Research, 325, 129-136. http://dx.doi.org/10.1016/0165-7992(94)90075-2

[34] Azizan, A. and Blevins, R.D. (1995) Mutagenicity and Antimutagenicity Testing of Six Chemicals Associated with the Pungent Properties of Specific Spices as Revealed by the Ames Salmonella/Microsomal Assay. Archives of Environmental Contamination and Toxicology, 28, 248-258. http://dx.doi.org/10.1007/BF00217624

[35] Stammati, A., Bonsi, P., Zucco, F., Moezelaar, R., Alakomi, H.L. and Von Wright, A. (1999) Toxicity of Selected Plant Volatiles in Microbial and Mammalian Short-Term Assays. Food and Chemical Toxicology, 37, 813-823. http://dx.doi.org/10.1016/S0278-6915(99)00075-7

[36] Dillon, D., Combes, R. and Zeiger, E. (1998) The Effectiveness of Salmonella Strains TA100, TA102 and TA104 for Detecting Mutagenicity of Some Aldehydes and Peroxides. Mutagenesis, 13, 19-26.

http://dx.doi.org/10.1093/mutage/13.1.19

[37] Ishidate, M., Sofuni, T., Yoshikawa, K., Hayashi, M., Nohmi, T., Sawada, M. and Matsuoka, A. (1984) Primary Mutagenicity Screening of Food Additives Currently Used in Japan. Food and Chemical Toxicology, 22, 623-636. http://dx.doi.org/10.1016/0278-6915(84)90271-0

[38] Chang, Y.C., Tai, K.W., Huang, F.M. and Huang, M.F. (2000) Cytotoxic and Non-Genotoxic Effects of Phenolic Compounds in Human Pulp Cell Cultures. Journal of Endodontics, 26, 440-443. http://dx.doi.org/10.1097/00004770-200008000-00002

[39] Whysner, J. and Williams, G.M. (1996) D-Limonene Mechanistic Data and Risk Assessment: Absolute Species-Specific Cytotoxicity, Enhanced Cell Proliferation, and Tumor Promotion. Pharmacology and Therapeutics, 71, 127-136. http://dx.doi.org/10.1016/0163-7258(96)00065-4

[40] Zamith, H.P., Vidal, M.N., Speit, G. and Paumgartten, F.J. (1993) Absence of Genotoxic Activity of Beta-Myrcene in the in Vivo Cytogenetic Bone Marrow Assay. Brazilian Journal of Medical and Biological Research, 26, 93-98. http://www.ncbi.nlm.nih.gov/pubmed/8220273

[41] Ellahuene, M.F., Perez-Alzola, L.P., Orellana-Valdebenito, M., Munoz, C. and Lafuente-Indo, N. (1994) Genotoxic Evaluation of Eugenol Using the Bone Marrow Micronucleus Assay. Mutation Research, 320, 175-180. http://dx.doi.org/10.1016/0165-1218(94)90044-2

[42] Woolverton, C.J., Fotos, P.G., Mokas, M.J. and Mermigas, M.E. (1986) Evaluation of Eugenol for Mutagenicity by the Mouse Micronucleus Test. Journal of Oral Pathology, 15, 450-453. http://dx.doi.org/10.1111/j.1600-0714.1986.tb00656.x 


\section{Abbreviations}

SMART: Somatic Mutation and Recombination Test

C. loureirii: Cinnamomum loureirii

A. dracunculus: Artemisia dracunculus

L. nobilis: Laurus nobilis

O. basilicum: Ocimum basilicum

R. officinallis: Rosmarinus officinallis

S. montan: Satureja montana

GC/MS: Gas Chromatography/Mass Spectrometry 